\title{
Synthesis and Characterization of a Molecularly Imprinted Polymer for Diclofenac Sodium Using (2-vinylpyridine and 2-hydroxyethyl metha acrylate) as the Complexing Monomer
}

\author{
Yehya Kamal Al-Bayati ${ }^{*}$
}

\author{
Ahmed Jalil Al-Safi ${ }^{2}$
}

Received 18/9/2017
Accepted 17/12/2017

\begin{abstract}
:
Four electrodes were synthesized based on molecularly imprinted polymers (MIPs). Two MIPs were prepared by using the diclofenac sodium (DFS) as the template, 2-hydroxy ethyl metha acrylate(2-HEMA) and 2-vinyl pyridine(2-VP) as monomers as well as divinyl benzene and benzoyl peroxide as cross linker and initiator respectively. The same composition used for prepared non-imprinted polymers (NIPs) but without the template (diclofenac sodium). To prepared the membranes electrodes used different plasticizers in PVC matrix such as: tris(2-ethyl hexyl) phosphate (TEHP), tri butyl phosphate (TBP), bis(2-ethyl hexyl) adipate (BEHA) and tritolyl phosphate (TTP). The characteristics studied the slop, detection limit, life time and linearity range of DFS-MIPs electrodes. The results were obtained from selectivity measurements on amino acids showed good response as well as pharmaceuticals analysis.
\end{abstract}

Keywords: Molecularly imprinted electrodes, Diclofenac sodium, potentiometric method, (2-HEMA), (2VP) monomers.

\section{Introduction:}

Diclofenac sodium has the structure, 2-[(2, 6-dichlorophenyl)amino] benzene acetic acid sodium salt Fig.1, which belongs to the group of non-steroidal anti-inflammatory drug (NSAID). That is widely used for the treatment of analgesic, rheumatoid arthritis, osteoarthritis and ankylosing spondylitis (1). It is used as an suitable on the treatment to chronic diseases like arthritis and pain after surgical operations. It facilitate pain and reduces inflammation (2). Water crystallizes diclofenac sodium which have melting point from $283-285{ }^{\circ} \mathrm{C}$ which dissolved at room temperature in deionized water, acetone ,methanol, acetonitrile, cyclohexane, $\mathrm{HCl}$, and phosphate buffer(3).

According to review, diclofenac sodium was determination by several methods such as HPLC(4), spectrophotometry(5), thin layer chromatography (6), GC-Mass(7) and spectroscopic methods (8).

${ }^{1,2}$ Chemistry Department, College of Science, University of Baghdad, Al-Jaderia, Baghdad, Iraq.

*Corresponding author: yahyaalbayti@yahoo.com

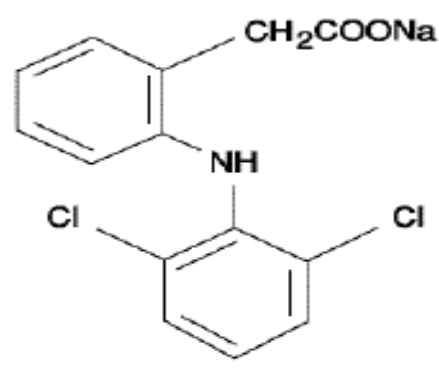

Figure 1. Chemical structure of the sodium diclofenac

An extensive literature survey revealed that there were several HPLC methods for the determination of diclofenac in blood plasma, whereas there was little other work disclosed only for the quantitative determination of diclofenac sodium in pharmaceutical formulation samples.

Selective electrodes were used as a technique for determination of di duo to several, rapid, easy preparation, fast response time, selectivity, wide linearity and low cost. For above characteristics that led to used sensors for the determination of ionic species, and the list of available electrodes has been grown largely over the past years(9-18). PVC membrane electrodes are one of the types of 
potentiometric sensors which were widely used and have different application in analysis of ionic species (19).

Molecularly imprinted polymers (MIPs) were used for drugs as formation a complex between the analyte and a functional monomer with presence of a cross-linking agent and initiator. Several reports described the use of MIPs as ionophores in ion selective electrodes for a variety of drugs and chemicals such as ibuprofen (20), warfarin (21), phenytoin (22) and metronidazole benzoate (23). In this work were prepared MIP by using 4-vinyl pyridine (4-VP) and 2-hydroxy metha acrylate (2HMA) as a monomers, divinyl benzene (DVB) as a cross-linker for polymerization with plasticizers tris (ethyl hexyl) phosphate (TEHP), tri butyl phosphate (TBP), bis(2-ethyl hexyl) adipate (BEHA), and tritolyl phosphate (TTP).

\section{Materials and Methods:}

\section{Preparation of MIP and NIP}

For the preparation of diclofenac sodium molecularly imprinted polymer (DFS-MIP), 0.5 mmol $(0.1590 \mathrm{~g})$ from DFS dissolved in methanol $\left(\mathrm{CH}_{3} \mathrm{OH}\right)$, then mixed with $2 \mathrm{mmol}(0.2102 \mathrm{~g}) 2-$ vinylpyridine (2-VP), $4.61 \mathrm{mmol}(0.6 \mathrm{~g})$ 2-hydroxy ethyl metha acrylate (2-HEMA) as the monomer which dissolved in $3 \pm \mathrm{mL}$ chloroform $\left(\mathrm{CHCl}_{3}\right)$, was after that added (1.3g) divinyl benzene to the solution as the cross linker, followed that added $(0.05 \mathrm{~g})$ benzoyl peroxide (BPO) as the initiator which also dissolved in $3 \pm \mathrm{mL}$ chloroform. For obtaining a homogeneous solution, the mixture was stirred for 5 minutes. $\mathrm{N}_{2}$ passes for 30 minutes on the mixture to remove oxygen from solution. After that the solution was placed in a water path at $65^{\circ} \mathrm{C}$. when the reaction completed the molecularly imprinted polymer became hardened. After the polymerization process, the polymer were dried and crashed to obtain a polymer particles. These particles was sonicated in $\mathrm{CH}_{3} \mathrm{OH} / \mathrm{CH}_{3} \mathrm{COOH}$ $(18: 2, \mathrm{v} / \mathrm{v})$ to remove the template from MIP. The particles size was between $(53-100 \mu \mathrm{m})$. The preparation of non-molecularly imprinted polymer using the same substances and conditions that formed MIP but without dicofenac sodium (template).

\section{Instruments:}

Ion analyzer used in this work (WTW model, Germany), a pH meter (WTW model pH 720,Germany), and a saturated calomel electrode (Gallenkamp, USA). The electrode diclofenac sodium-MIP used was constructed in the laboratory and all potentiometric measurements were made at room temperature. The diclofenac sodium-MIP electrode combined with $\mathrm{Ag}-\mathrm{AgCl}$ electrode and the reference electrode was $0.1 \mathrm{M}$ internal solution of diclofenac sodium. The PVC tube (1-2 cm long) was flattened and polished by putting it on a glass plate and soaking with THF. The membrane was cut similar to the external diameter of the PVC tubing and pasted on the polished end. The other direction of the PVC tubing was then linked to the electrode body. To make the electrodes more sensitive were by soaking in $0.1 \mathrm{M}$ diclofenac sodium solution for at least 2 hours before the use of the electrodes.

\section{Materials and chemicals:}

1. Diclofenac sodium standard obtained from industries of pharmaceuticals (IRAQ-SDI -Samara). Cata flam tablet $50 \mathrm{mg}$ from (Novartis pharma AG, Basle, Switzerland), Voldic-K tablet $50 \mathrm{mg}$ from (Pharma International CO. Amman -Jordan) and OPIFENAC-25 tablet $50 \mathrm{mg}$ (Ajanta Pharma, India) were purchased from local pharmacies.

2. Plasticizers, Tris (2-ethyl hexyl) phosphate (TEHP) (97.0\% purity), tri-butyl phosphate (TBP) (99.0\% purity), Bis( 2-ethyl hexyl ) adipate (BEHA) (99\% purity) and Tritolyl phosphate (TTP) (94\% purity) were purchased from Fluka AG. Other chemicals and reagents materials were obtained from Fluka, BDH and Sigma Aldrich.

\section{Preparing of Standard solutions}

1.For preparing standard solution of $0.1 \mathrm{M}$ diclofenac sodium by dissolving $0.159 \mathrm{~g}$ of standard diclofenac sodium in the methanol and completed to $100 \mathrm{~mL}$ in the volumetric flask. The other solutions were prepared in $100 \mathrm{~mL}$ at the ranged from $10^{-6}-$ $10^{-1} \mathrm{M}$ in the same procedure.

2 . The stock standard solution of $5 \times 10^{-3} \mathrm{M}, 5 \times 10^{-4}$ M phospho molybdic acid was prepared by dissolving $0.912 \mathrm{~g}, 0.091 \mathrm{~g}$ respectively in distilled water and completed to $100 \mathrm{~mL}$.

3. All amino acids $0.1 \mathrm{M}$ stock solution prepared at ranged from $\left(10 x^{-6}-10 x^{-1}\right) M$ which present the interfering ions such; asparagine, arginine, glycine, tryptophan, were prepared and diluted to $100 \mathrm{~mL}$.

\section{Synthesis of membrane molecularly imprinted} polymers electrode

Diclofenac sodium membrane was immobilized into the PVC tube as portrayed by Thomas and Moody(24). DFS-MIP of $(0.04 \mathrm{~g})$ was mixed with different of plasticizers $(0.8 \mathrm{~g})$ used in this work such as: TEHP (electrode A1), TBP (electrode A2), BEHA (electrode B1) and TTP (electrode B2). Then added $(0.34 \mathrm{~g})$ of PVC powder was scattered on $7 \pm$ $\mathrm{mL}$ of tetrahydrofuran with stirring until a clear viscous solution was acquired. Then the solutions mixed with stirring until the mixture were became homogeneous . The mixture was casted into a glass ring (30-35 mm diameter) and unwind on a glass plate and a ribbon of filter was placed on top of the 
glass. The solvent was then allowed to evaporate according to room temperature more than 24 hours at least .The thickness of the membrane obtained was different of membrane to other's, the thickness was about $(0.4-0.7) \mathrm{mm}$. That size of membrane was adequate to prepare electrodes.

\section{Scanning Electron Microscope SEM}

The morphology of MIP and NIP membranes with and without conditioning has assessed by scanning electron microscope [JSM-6390A] (Tokyo,japan) for MIP1 is shown in Figure. 2. Fig. 2a shows a numerous pores on the surface which made it a suitable sorbent because of the well-defined binding sites on the imprinted polymer. In addition, the image shows that the diameters of MIP1 are uniform in sizes and shapes (regular spherical). Fig. $2 b$ shows that the MIP1 is bound to the holes of MIP1, indicating that the MIP1 can be used as a selective sensor for diclofenac sodium template in the solution. The differences between the SEM images of MIP and NIP in terms of size and surface morphology of the polymeric particles are clearly can be observed.

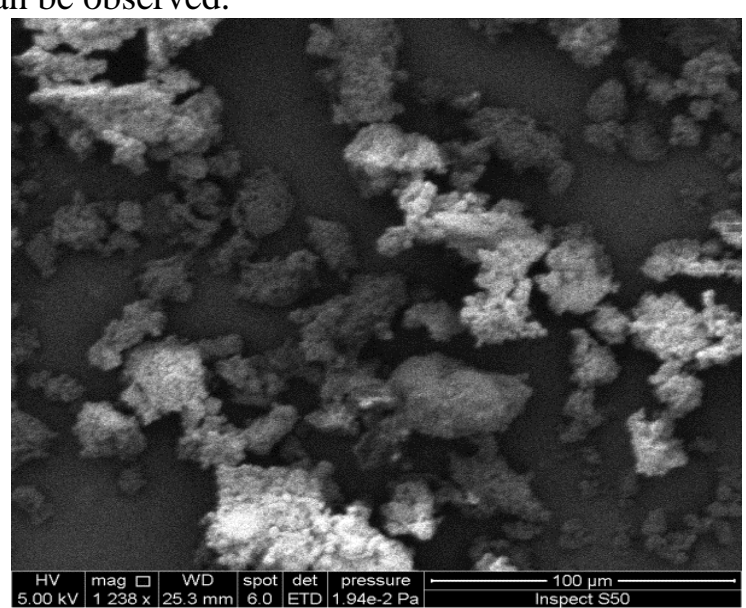

Figure 2a. SEM for the MIP1 before washing

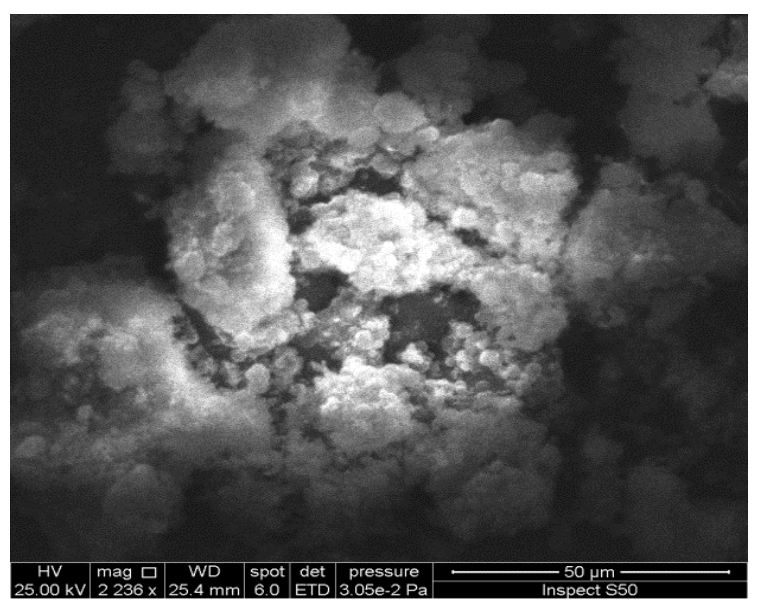

Figure 2b. SEM for MIP1after washing
The morphology of the prepared membrane using the DFS-MIP1 before washing is shown in figure $2 \mathrm{a}$ and after washing is shown in Fig $2 b$.

Figure $2 \mathrm{a}$ (before washing) reveals that the particles of the complex are formed in a regular spherical shape with an average of about $200 \mu \mathrm{m}$ in diameter. On the other hand, Fig $2 b$ (after washing) shows that the formed particles look like a colloidal particles growing in a solution. This might take place due to a presence of excess of DFS that forms ionic atmosphere surrounding the complex and create the formation of electric double layers.

\section{Construction of ion-selective electrodes}

The building of the electrode body and the immobilization were achieved as portrayed by Mahajan et al.(25). Diclofenac sodium solution (0.1) $\mathrm{M}$ was filled in the glass tube as an internal solution. Preferred immersing. The membrane in standard solution of (0.1) $\mathrm{M}$ of diclofenac sodium for at least two hours before measurements which represents stipulations of membrane electrode.

\section{Preparation of Pharmaceutical Samples}

To obtain the powder of tablets pharmaceutical samples using pestle and mortar to grinding the tablets then take a suitable weight for preparation in $100 \mathrm{~mL}$ of solutions .Used appropriate amount of methanol $\left(\mathrm{CH}_{3} \mathrm{OH}\right)$ for dissolved pharmaceutical samples as well as using the magnetic stirrer for more than 30 minutes .After that filtered the solution by using $0.07 \mu \mathrm{m}$ cellulose filter paper for preparing and obtained the concentrations of $5 \times 10^{-3}$ $\mathrm{M}$ and $5 \times 10^{-4} \mathrm{M}$ diclofenac sodium.

\section{Results and Discussion:}

The largest group of potentiometric sensors is represented by ion selective electrodes (ISEs). The signal is generated by the charge separation at the interface between the membrane and the solution, due to the selective partitioning of ionic species between these two phases (26). A line diagram of the ISE cell can be represented by the Fig (3).

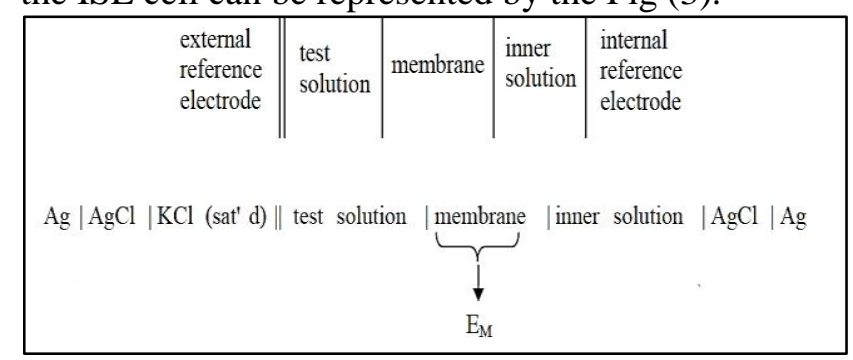

Figure 3. A line diagram of the ISE cell.

And the potential of (ISE) cell is given by the equation: (6)

$\mathbf{E}_{\text {cell }}=\left(\mathbf{E}_{\mathbf{m}}-\mathbf{E}_{\text {ref }}\right)+\mathbf{E}_{\mathbf{j}}$

Where: 
$\mathbf{E}_{\mathbf{m}}=$ is the membrane potential.

A plasticizer is an important component in an ISE membrane. The plasticizer acts as a membrane solvent, affecting membrane selectivity through both extraction of ions into the organic phase and influencing their complexation with the ionophore. Synthesis molecularly imprinted polymers by using the diclofenac sodium as template, 2-vinyl pyridine or 2-hydroxy metha acrylate as monomers, divinyl benzene as cross linker and benzoyl peroxide as initiator. Used four plasticizers for preparations electrodes based on PVC membranes. These plasticizers such as: tris(2-ethyl hexyl) phosphate (TEHP), tri butyl phosphate (TBP), bis(2-ethyl hexyl )adipate (BEHA) and tritolyl phosphate (TTP). The nernstain slopes for all electrodes bases on DFS-MIP1 (A1, A2 membranes) and DFS-MIP2 (B1, B2 membranes) were obtained, linearity range, correlation coefficients, detection limit (M) and life time (day) respectively are shown in the table1and Fig 4.

Table 1. Characteristics of the diclofenac sodium-MIP electrode based on different functional monomers and plasticizers.

\begin{tabular}{|c|c|c|c|c|}
\hline Membrane composition & $\begin{aligned} & \text { DFS-MIP1 } \\
&+ \text { TEHP ( A1) }\end{aligned}$ & $\begin{array}{c}\text { DFS-MIP1+TBP } \\
\text { (A2) }\end{array}$ & $\begin{array}{c}\text { DFS-MIP2 } \\
+ \text { BEHA (B1) }\end{array}$ & $\begin{array}{c}\text { DFS-MIP2 +TTP } \\
\text { (B2) }\end{array}$ \\
\hline Slop (mV/decade) & 18.5 & 21.98 & 22.04 & 17.33 \\
\hline Linearity range $(\mathrm{M})$ & $10^{-2}-10^{-4}$ & $10^{-1}-10^{-5}$ & $10^{-1}-10^{-3}$ & $10^{-3}-10^{-6}$ \\
\hline Correlation coefficient & 0.9987 & 0.9962 & 0.9965 & 0.9941 \\
\hline Detection limit (M) & $3 \times 10^{-6}$ & $2 \times 10^{-6}$ & $4 \times 10^{-6}$ & $6 \times 10^{-6}$ \\
\hline Life time ( day ) & 46 & 14 & 11 & 8 \\
\hline
\end{tabular}

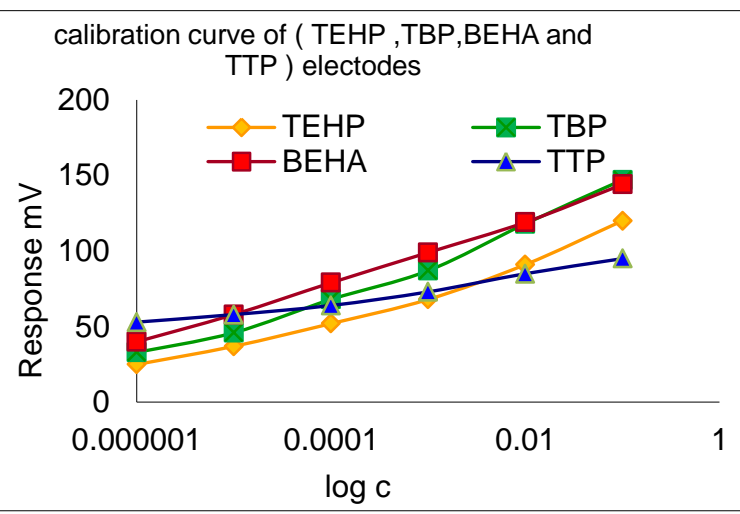

Figure 4. Calibration curve for DFS-MIP1 and DFS-MIP2 membranes electrodes.

\section{Effect of $\mathrm{pH}$ on electrodes response}

The study of $\mathrm{pH}$ affected DFS membranes electrodes by prepared various concentrations of DFS $\left(5 \times 10^{-3}, 5 \times 10^{-4}\right.$ and $\left.5 \times 10^{-5}\right)$. To measure the selective $\mathrm{pH}$ at ranged (1-11) by using the hydrochloric acid $(0.1 \mathrm{M}, 1 \mathrm{M})$ and/or ammonium hydroxide $(0.1 \mathrm{M}, 1 \mathrm{M})$ for $\mathrm{pH}$ studies. The results obtained by adding appropriate volume of $\mathrm{HCl} / \mathrm{NH}_{4} \mathrm{OH}$ as shown in Table (2) and Fig. $(5,6)$.The change in potentials at differential $\mathrm{pH}$ values may be due to the composition of electrodes. This composition also effect on response and life time for electrodes.

Table 2. Working pH range for diclofenac sodium Selective electrode

\begin{tabular}{|c|c|c|c|c|c|}
\hline \multirow{2}{*}{$\begin{array}{c}\text { Number and } \\
\text { composition of MIPs }\end{array}$} & \multirow{2}{*}{ Membranes } & \multirow{2}{*}{$\begin{array}{c}\text { Membrane } \\
\text { composition }\end{array}$} & \multicolumn{3}{|c|}{ pH range } \\
\hline & & & $5 \times 10^{-3}$ & $5 \times 10^{-4}$ & $5 \times 10^{-5}$ \\
\hline MIP1 & A1 & DFS-MIP1 +TEHP & $8-11$ & $7.5-11$ & $5-11$ \\
\hline $\mathrm{DFS}+2-\mathrm{VP}+\mathrm{DVB}$ & A2 & DFS-MIP1 +TBP & $4.5-9$ & $5-11$ & $5-10.5$ \\
\hline MIP2 & B1 & DFS-MIP2+BEHA & $5.5-11$ & $5.5-11$ & $7.5-9.5$ \\
\hline DFS+2-HEMA+DVB & B2 & DFS-MIP2 +TTP & $6.5-11$ & $6.5-11$ & $5.5-11$ \\
\hline
\end{tabular}
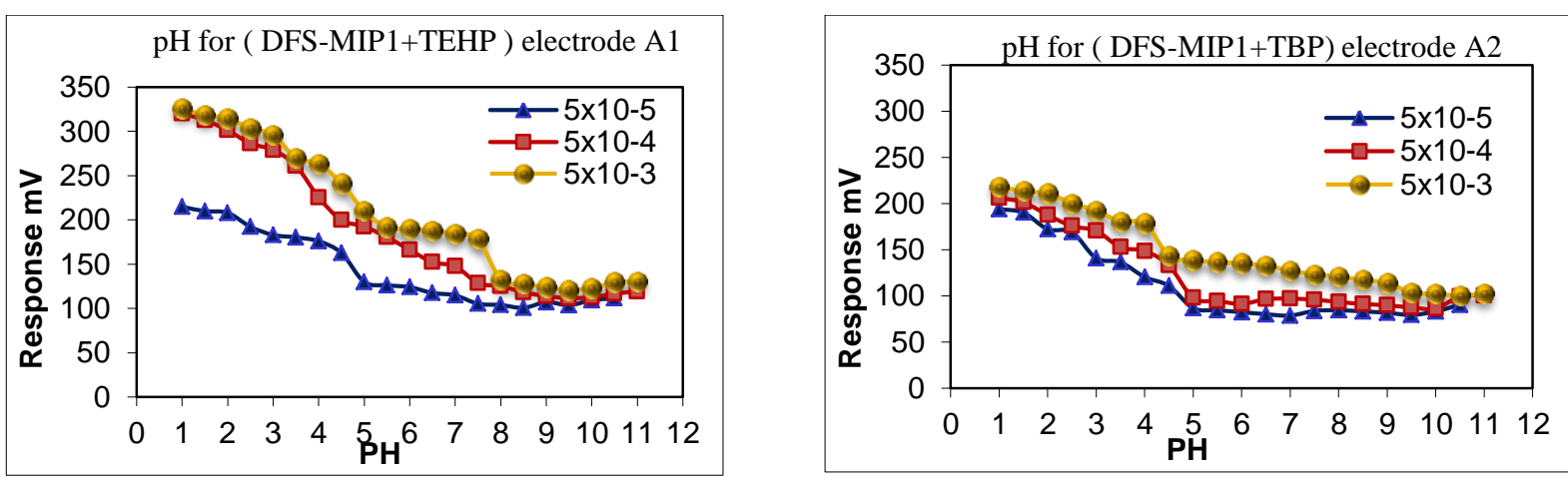

Figure 5. Effect of pH on the Diclofenac Sodium \{DFS-MIP1 + TEHP (A1) and DFS-MIP1 +TBP (A2) $\}$ electrodes at concentration $5 \times 10^{-3}, 5 \times 10^{-4}$ and $5 \times 10^{-5}$. 

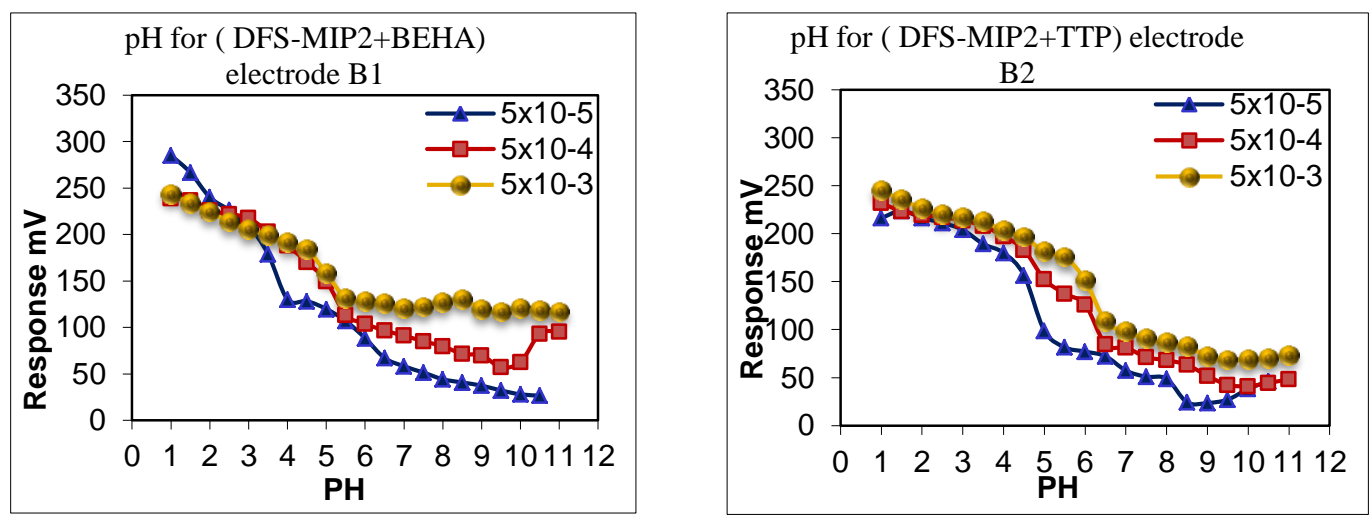

Figure 6. Effect of pH on the Diclofenac Sodium \{DFS-MIP2 + BEHA (B1) and DFS-MIP2 +TTP (B2)\} electrodes at concentration $5 \times 10^{-3}, 5 \times 10^{-4}$ and $5 \times 10^{-5}$.

\section{Interference studies}

For calculating the selectivity, coefficient measurement used separate solution method. Using the separate equation for this measurements according to the equation below.

$\log K$ pot $=[(E B-E A) /(2.303 R T / z F)]+(1-z A / z B)$ $\log \mathbf{a A}$

$\mathrm{EA}, \mathrm{EB} ; \mathrm{zA}, \mathrm{zB}$; and $\mathrm{aA}$, represents the potentials, charge numbers, and activities for the primary $A$ and interfering $\mathrm{B}$ ions, respectively at $\mathrm{aA}=\mathrm{aB}$.
The results obtained for selectivity coefficients of primary ion and interfering ions like amino acids used in this work. The selectivity coefficients depend on charges of both primary ion and interfering ions it also depends on concentration as well as the composition of electrodes (27).

All values for selectivity coefficients were listed in tables 3, 4, 5, 6 and figures $(7,8)$.

Table 3. Selectivity coefficients for (DFS -MIP1 + TEHP) electrode at different concentrations of Diclofenac sodium

\begin{tabular}{|c|c|c|c|c|c|c|c|c|}
\hline \multirow{4}{*}{ Conc.(M) } & \multicolumn{8}{|c|}{ Concentrations of Diclofenac Sodium (M): Concentrations of interference ions (M) } \\
\hline & \multicolumn{8}{|c|}{$\begin{array}{ll}\text { Interfering ions } \\
\end{array}$} \\
\hline & \multicolumn{2}{|c|}{ Asparagine } & \multicolumn{2}{|c|}{ Arginine } & \multicolumn{2}{|c|}{ Glycine } & \multicolumn{2}{|c|}{ Tryptophan } \\
\hline & $\begin{array}{c}\mathrm{E}_{\mathrm{B}} \\
(\mathrm{mV})\end{array}$ & $\mathrm{K}_{\mathrm{A}, \mathrm{B}}$ & $\begin{array}{c}\mathrm{E}_{\mathrm{B}} \\
(\mathrm{mV})\end{array}$ & $\mathrm{K}_{\mathrm{A}, \mathrm{B}}$ & $\begin{array}{c}\mathrm{E}_{\mathrm{B}} \\
(\mathrm{mV})\end{array}$ & $\mathrm{K}_{\mathrm{A}, \mathrm{B}}$ & $\begin{array}{c}\mathrm{E}_{\mathrm{B}} \\
(\mathrm{mV})\end{array}$ & $\mathrm{K}_{\mathrm{A}, \mathrm{B}}$ \\
\hline $10^{-1}$ & 100.4 & $2.0932 \times 10^{-4}$ & 61.2 & $6.6925 \times 10^{-7}$ & 78 & $7.8518 \times 10^{-6}$ & 88.1 & $3.4504 \times 10^{-5}$ \\
\hline $10^{-2}$ & 88.2 & $5.7463 \times 10^{-3}$ & 71.4 & $4.8979 \times 10^{-4}$ & 73.7 & $6.8614 \times 10^{-4}$ & 85.4 & $6.2929 \times 10^{-5}$ \\
\hline $10^{-3}$ & 75.6 & $2.0268 \times 10^{-2}$ & 80.6 & $4.2177 \mathrm{E}-0^{-2}$ & 67.5 & $6.1832 \times 10^{-3}$ & 76.7 & $2.3814 \times 10^{-2}$ \\
\hline $10^{-4}$ & 73 & $1.6008 \times 10^{-1}$ & 76.3 & $2.5965 \times 10^{-1}$ & 61.2 & $2.8393 \times 10^{-2}$ & 70.1 & $1.0465 \times 10^{-1}$ \\
\hline $10^{-5}$ & 68.9 & $1.6244 \times 10^{-1}$ & 70.9 & $2.1777 \times 10^{-1}$ & 60.9 & $5.0288 \times 10^{-2}$ & 62.5 & $6.3578 \times 10^{-2}$ \\
\hline $10^{-6}$ & 73.1 & $5.8141 \times 10^{-1}$ & 68.7 & $3.0507 \times 10^{-1}$ & 59.3 & $7.6924 \times 10^{-2}$ & 63.6 & $1.4447 \times 10^{-1}$ \\
\hline
\end{tabular}

Table 4. Selectivity coefficients for (DFS -MIP1 +TBP) electrode at different concentrations of Diclofenac sodium.

\begin{tabular}{|c|c|c|c|c|c|c|c|c|}
\hline \multirow{4}{*}{ Conc.(M) } & \multicolumn{8}{|c|}{ Concentrations of Diclofenac Sodium (M): Concentrations of interference ions (M) } \\
\hline & \multicolumn{8}{|c|}{ Interfering ions } \\
\hline & \multicolumn{2}{|c|}{ Asparagine } & \multicolumn{2}{|r|}{ Arginine } & \multicolumn{2}{|r|}{ Glycine } & \multicolumn{2}{|c|}{ Tryptophan } \\
\hline & $\begin{array}{c}\mathrm{E}_{\mathrm{B}} \\
(\mathrm{mV})\end{array}$ & $\mathrm{K}_{\mathrm{A}, \mathrm{B}}$ & $\begin{array}{c}\mathrm{E}_{\mathrm{B}} \\
(\mathrm{mV})\end{array}$ & $\mathrm{K}_{\mathrm{A}, \mathrm{B}}$ & $\begin{array}{c}\mathrm{E}_{\mathrm{B}} \\
(\mathrm{mV})\end{array}$ & $\mathrm{K}_{\mathrm{A}, \mathrm{B}}$ & $\begin{array}{c}\mathrm{E}_{\mathrm{B}} \\
(\mathrm{mV})\end{array}$ & $\mathrm{K}_{\mathrm{A}, \mathrm{B}}$ \\
\hline $10^{-1}$ & 106.4 & $1.6470 \times 10^{-3}$ & 109 & $2.3910 \times 10^{-3}$ & 71.9 & $3.1871 \times 10^{-5}$ & 82.6 & $5.4293 \times 10^{-5}$ \\
\hline $10^{-2}$ & 92.1 & $1.3169 \times 10^{-2}$ & 88.1 & $7.4214 \times 10^{-3}$ & 66.1 & $3.8398 \times 10^{-4}$ & 77.3 & $1.5776 \times 10^{-3}$ \\
\hline $10^{-3}$ & 81.6 & $9.6618 \times 10^{-2}$ & 81.4 & $9.3886 \times 10^{-2}$ & 58.3 & $4.7597 \times 10^{-3}$ & 74.5 & $3.4911 \times 10^{-2}$ \\
\hline $10^{-4}$ & 66.3 & $1.2687 \times 10^{-1}$ & 77.6 & $6.4117 \times 10^{-1}$ & 49.6 & $9.0267 \times 10^{-3}$ & 61.7 & $6.5605 \times 10^{-2}$ \\
\hline $10^{-5}$ & 61.1 & $1.6189 \times 10^{-1}$ & 71.9 & $7.6154 \times 10^{-1}$ & 46.4 & $4.9742 \times 10^{-2}$ & 59.2 & $1.2328 \times 10^{-1}$ \\
\hline $10^{-6}$ & 65.7 & $4.5450 \times 10^{-1}$ & 59.3 & $1.8156 \times 10^{-1}$ & 50.2 & $1.2014 \times 10^{-1}$ & 53.1 & $7.4641 \times 10^{-2}$ \\
\hline
\end{tabular}


Table 5. Selectivity coefficients for (DFS -MIP2 +BEHA) electrode at different concentrations of Diclofenac sodium.

Concentrations of Diclofenac Sodium (M): Concentrations of interference ions (M)

\begin{tabular}{|c|c|c|c|c|c|c|c|c|}
\hline \multirow{3}{*}{ Conc.(M) } & \multicolumn{8}{|c|}{ Interfering ions } \\
\hline & \multicolumn{2}{|c|}{ Asparagine } & \multicolumn{2}{|c|}{ Arginine } & \multicolumn{2}{|c|}{ Glycine } & \multicolumn{2}{|c|}{ Tryptophan } \\
\hline & $\begin{array}{c}\mathrm{E}_{\mathrm{B}} \\
(\mathrm{mV})\end{array}$ & $\mathrm{K}_{\mathrm{A}, \mathrm{B}}$ & $\begin{array}{c}\mathrm{E}_{\mathrm{B}} \\
(\mathrm{mV})\end{array}$ & $\mathrm{K}_{\mathrm{A}, \mathrm{B}}$ & $\begin{array}{c}\mathrm{E}_{\mathrm{B}} \\
(\mathrm{mV})\end{array}$ & $\mathrm{K}_{\mathrm{A}, \mathrm{B}}$ & $\begin{array}{c}\mathrm{E}_{\mathrm{B}} \\
(\mathrm{mV})\end{array}$ & $\mathrm{K}_{\mathrm{A}, \mathrm{B}}$ \\
\hline $10^{-1}$ & 143.5 & $7.4148 \times 10^{-3}$ & 47.6 & $4.3410 \times 10^{-6}$ & 79.3 & $4.6875 \times 10^{-4}$ & 126.4 & $7.4048 \times 10^{-4}$ \\
\hline $10^{-2}$ & 123.1 & $1.4941 \times 10^{-2}$ & 44.3 & $6.5838 \times 10^{-4}$ & 72 & $3.9378 \times 10^{-2}$ & 120.7 & $1.0813 \times 10^{-2}$ \\
\hline $10^{-3}$ & 112.7 & $8.1591 \times 10^{-2}$ & 38.7 & $2.3448 \times 10^{-3}$ & 64.8 & $1.1073 \times 10^{-1}$ & 101 & $1.6867 \times 10^{-2}$ \\
\hline $10^{-4}$ & 82.3 & $8.5993 \times 10^{-3}$ & 48.1 & $6.7015 \times 10^{-2}$ & 59.6 & $3.6629 \times 10^{-1}$ & 93.3 & $3.7854 \times 10^{-2}$ \\
\hline $10^{-5}$ & 72.9 & $1.3057 \times 10^{-2}$ & 36 & $9.2744 \times 10^{-2}$ & 47.5 & $5.0692 \times 10^{-1}$ & 80.5 & $3.6355 \times 10^{-2}$ \\
\hline $10^{-6}$ & 66 & $2.8144 \times 10^{-2}$ & 21.9 & $1.6233 \times 10^{-2}$ & 33 & $8.3635 \times 10^{-2}$ & 76.7 & $1.1898 \times 10^{-1}$ \\
\hline
\end{tabular}

Table 6. Selectivity coefficients for (DFS -MIP2 + TTP) electrode at different concentrations of Diclofenac Sodium.

Concentrations of Diclofenac Sodium (M): Concentrations of interference ions (M)

\begin{tabular}{|c|c|c|c|c|c|c|c|c|}
\hline \multirow{4}{*}{ Conc.(M) } & \multicolumn{8}{|c|}{ Concentrations of Diclofenac Sodium (M): Concentrations of interference ions (M) } \\
\hline & \multicolumn{8}{|c|}{ Interfering ions } \\
\hline & \multicolumn{2}{|c|}{ Asparagine } & \multicolumn{2}{|c|}{ Arginine } & \multicolumn{2}{|c|}{ Glycine } & \multicolumn{2}{|c|}{ Tryptophan } \\
\hline & $\begin{array}{c}\mathrm{E}_{\mathrm{B}} \\
(\mathrm{mV})\end{array}$ & $\mathrm{K}_{\mathrm{A}, \mathrm{B}}$ & $\begin{array}{c}\mathrm{E}_{\mathrm{B}} \\
(\mathrm{mV})\end{array}$ & $\mathrm{K}_{\mathrm{A}, \mathrm{B}}$ & $\begin{array}{c}\mathrm{E}_{\mathrm{B}} \\
(\mathrm{mV})\end{array}$ & $\mathrm{K}_{\mathrm{A}, \mathrm{B}}$ & $\begin{array}{c}\mathrm{E}_{\mathrm{B}} \\
(\mathrm{mV})\end{array}$ & $\mathrm{K}_{\mathrm{A}, \mathrm{B}}$ \\
\hline $10^{-1}$ & 105.3 & $2.5865 \times 10^{-4}$ & 70.6 & $2.1436 \times 10^{-6}$ & 66.7 & $1.2508 \times 10^{-6}$ & 54.8 & $2.4173 \times 10^{-7}$ \\
\hline $10^{-2}$ & 96.5 & $2.5022 \times 10^{-2}$ & 68.9 & $5.5291 \times 10^{-4}$ & 60.9 & $1.8312 \times 10^{-4}$ & 56.5 & $9.9724 \times 10^{-5}$ \\
\hline $10^{-3}$ & 87.7 & $5.3488 \times 10^{-2}$ & 65.1 & $2.3579 \times 10^{-3}$ & 55.5 & $6.2610 \times 10^{-4}$ & 60.1 & $1.1819 \times 10^{-3}$ \\
\hline $10^{-4}$ & 67.5 & $1.4008 \times 10^{-2}$ & 64.7 & $9.5149 \times 10^{-3}$ & 50.8 & $1.3950 \times 10^{-3}$ & 71.7 & $2.5022 \times 10^{-2}$ \\
\hline $10^{-5}$ & 63.9 & $6.0568 \times 10^{-2}$ & 50.4 & $9.3844 \times 10^{-3}$ & 55.9 & $2.0060 \times 10^{-2}$ & 69.1 & $1.2422 \times 10^{-1}$ \\
\hline $10^{-6}$ & 58.4 & $1.1754 \times 10^{-1}$ & 48.1 & $2.8334 \times 10^{-2}$ & 65.1 & $2.9656 \times 10^{-1}$ & 71.9 & $7.5862 \times 10^{-1}$ \\
\hline
\end{tabular}
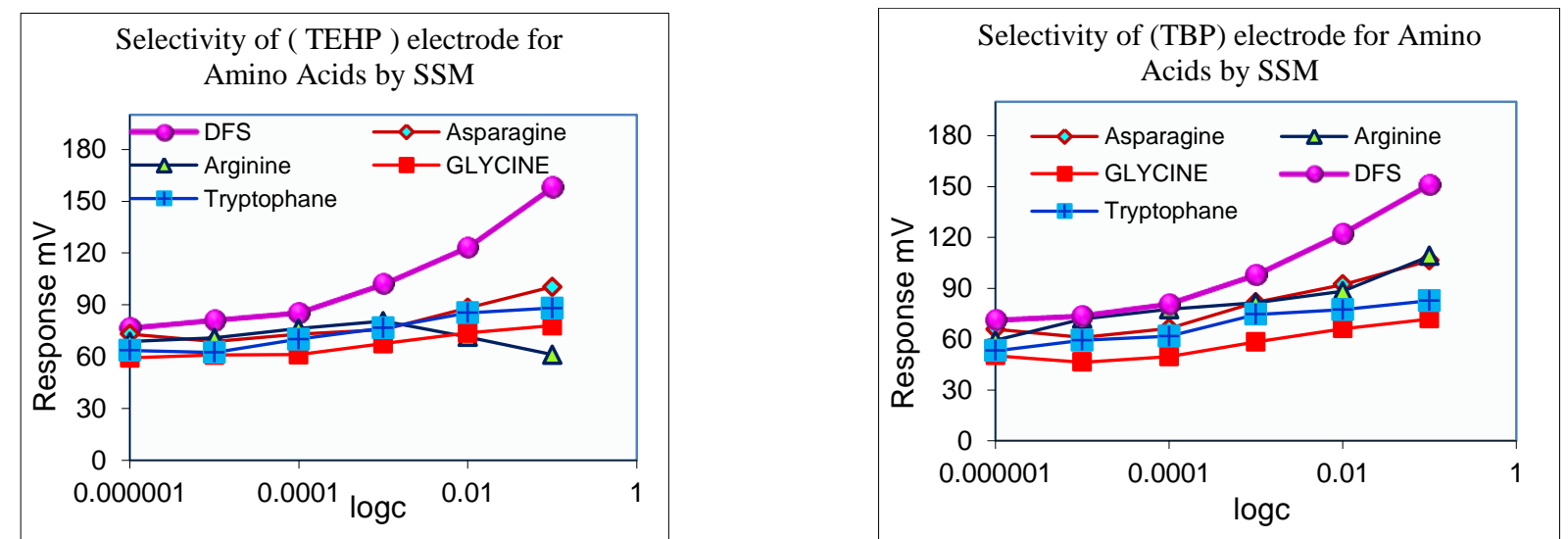

Figure 7. Selectivity of (DFS-MIP 1 + TEHP and DFS-MIP 1 + TBP) electrodes with amino acids via Separation Solution Method.
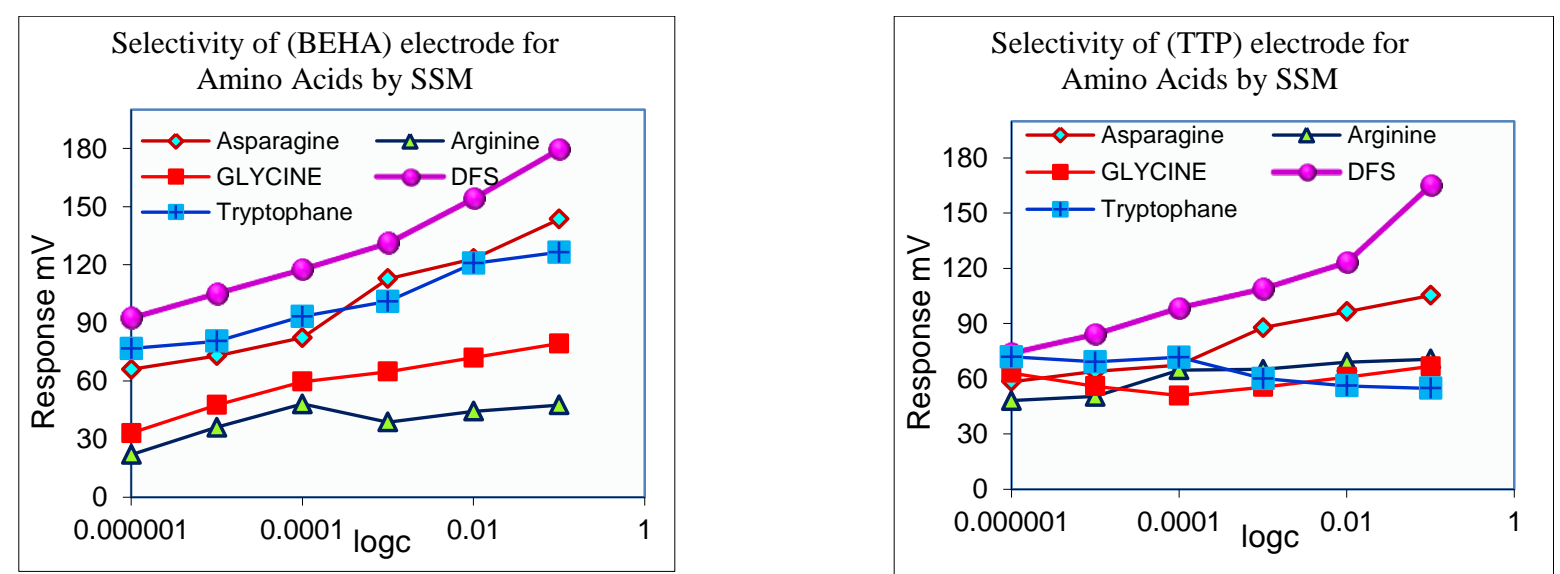

Figure 8. Selectivity of (DFS-MIP 2 + BEHA and DFS-MIP 2 + TTP) electrodes with amino acids via Separation Solution Method. 


\section{Calculation by Multiple Standard Addition} Method (MSA):

The concentrations used for applied in this method $\left(5 \times 10^{-3} \& 5 \times 10^{-4}\right)$ for two solutions of diclofenac sodium for plotting the antilog E/S (Y-axis) against volume of standard diclofenac sodium (X-axis). Fig. $(9,10)$ represents the results of diclofenac sodium concentrations calculated via the electrodes based on DFS-MIP1+ TBP, DFS-MIP2+BEHA.

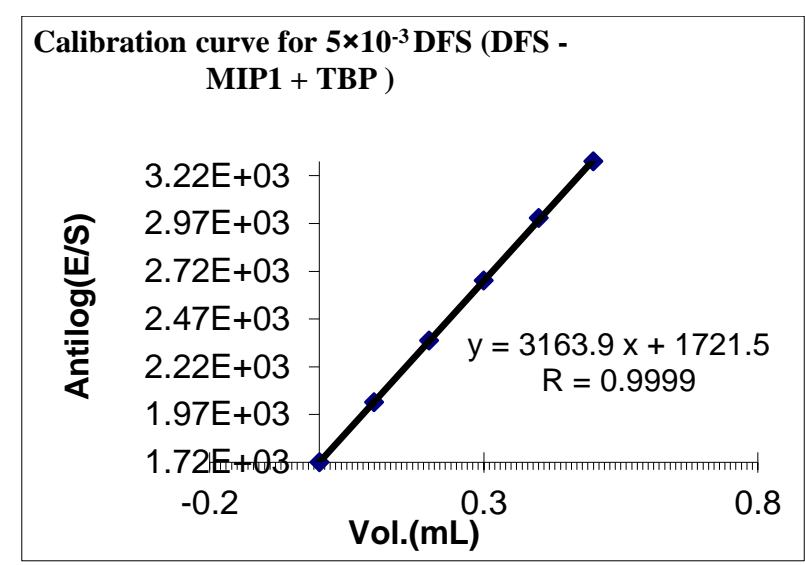

Figure 9. Antilog (E/S) against the volume of the added standard for the determination of

Diclofenac Sodium solution $\left(5 \times 10^{-3}\right)$ by MSA using (DFS - MIP 1 + TBP) electrode.

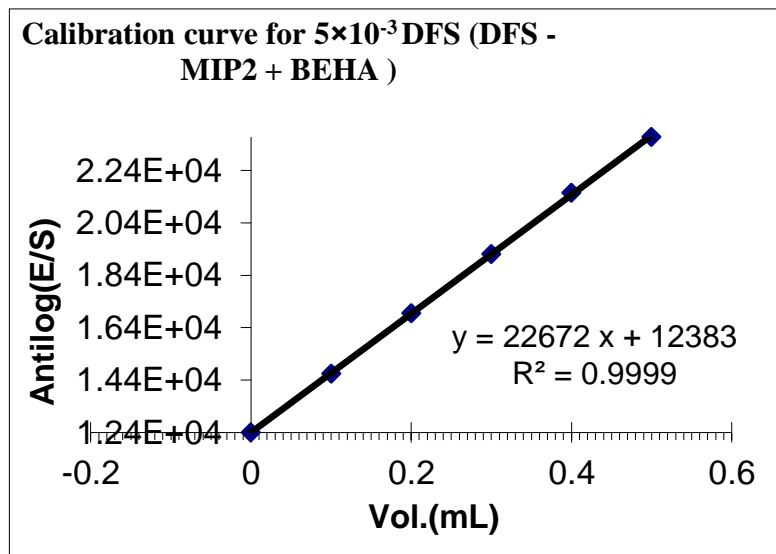

Figure 10. Antilog (E/S) against the volume of the added standard for the determination of Diclofenac Sodium solution $\left(5 \times 10^{-3}\right)$ by MSA using (DFS - MIP 2 + BEHA) electrode.

\section{Applications of pharmaceuticals \\ Ion selective electrodes that based on molecularly imprinted polymers were used for determination of diclofenac sodium in pharmaceuticals. This ISEs measurements including: standard addition, direct, Gran plot and multiple standard addition method. Preparation solutions of diclofenac sodium at concentrations $5 \times 10^{-3}$ and $5 \times 10^{-4} \mathrm{M}$. The RE\%, $\mathrm{RC} \%$ and $\mathrm{RSD} \%$ were calculated of diclofenac sodium in pharmaceuticals. The results obtained are represented in tables $(9,10,11$, and 12).}

Table 9. Analysis of Diclofenac sodium samples by using ISE type ( DFS-MIP1+TEHP)

\begin{tabular}{|c|c|c|c|}
\hline \multirow{2}{*}{ Pharmaceutical } & \multicolumn{3}{|c|}{ CataFlam ( Novartis pharma AG, Basle, Switzerland ) } \\
\hline & DM & SAM & MSAM \\
\hline Concentration $\mathbf{M}$ & & $5 \times 10-3$ & \\
\hline Value founded & $5.0673 \times 10-3$ & $4.9483 \times 10-3$ & $5.0636 \times 10-3$ \\
\hline Recovery \% & 101.35 & 98.97 & 101.27 \\
\hline $\mathrm{RE} \%$ & 1.35 & -1.03 & 1.27 \\
\hline $\mathrm{RSD} \%$ & 2.2707 & 1.12 & \\
\hline Pharmaceutical & \multicolumn{3}{|c|}{ OPIFENAC-25 (Ajanta Pharma, India) } \\
\hline Concentration $\mathbf{M}$ & & $5 \times 10-3$ & \\
\hline Value founded & $5.0852 \times 10-3$ & $4.9937 \times 10-3$ & $4.9248 \times 10-3$ \\
\hline Recovery \% & 101.70 & 99.87 & 98.50 \\
\hline $\mathrm{RE} \%$ & 1.70 & -0.13 & -1.50 \\
\hline $\mathrm{RSD} \%$ & 1.8594 & 1.35 & \\
\hline Pharmaceutical & \multicolumn{3}{|c|}{ Voldic-K ( Pharma International CO . Amman -Jordan ) } \\
\hline Concentration $\mathbf{M}$ & & $5 \times 10-3$ & \\
\hline Value founded & $5.0728 \times 10-3$ & $4.9385 \times 10-3$ & $5.0946 \times 10-3$ \\
\hline Recovery \% & 101.46 & 98.77 & 101.89 \\
\hline $\mathrm{RE} \%$ & 1.46 & -1.23 & 1.89 \\
\hline $\mathrm{RSD} \%$ & 2.2403 & 1.14 & - \\
\hline
\end{tabular}


Table 10. Analysis of Diclofenac sodium samples by using ISE type (DFS-MIP1 +TBP)

\begin{tabular}{|c|c|c|c|}
\hline \multirow{2}{*}{ Pharmaceutical } & \multicolumn{3}{|c|}{ CataFlam ( Novartis pharma AG, Basle, Switzerland ) } \\
\hline & DM & SAM & MSAM \\
\hline Concentration $\mathrm{M}$ & & $5 \times 10-3$ & \\
\hline Value founded & $4.9468 \times 10-3$ & $4.8864 \times 10-3$ & $5.0415 \times 10-3$ \\
\hline Recovery \% & 98.94 & 97.73 & 100.83 \\
\hline RE\% & -1.06 & -2.27 & 0.83 \\
\hline $\mathrm{RSD} \%$ & 2.191 & 1.07 & - \\
\hline Pharmaceutical & \multicolumn{3}{|c|}{ OPIFENAC-25 (Ajanta Pharma, India) } \\
\hline Concentration $\mathrm{M}$ & & $5 \times 10-3$ & \\
\hline Value founded & $5.0739 \times 10-3$ & $4.9975 \times 10-3$ & $5.080 \times 10-3$ \\
\hline Recovery \% & 101.48 & 99.95 & 101.60 \\
\hline RE\% & 1.48 & -0.05 & 1.60 \\
\hline $\mathrm{RSD} \%$ & 2.33 & 1.32 & - \\
\hline RSD\% & 1.721 & 1.37 & - \\
\hline Pharmaceutical & \multicolumn{3}{|c|}{ Voldic-K (Pharma International CO . Amman -Jordan ) } \\
\hline Concentration $\mathrm{M}$ & & $5 \times 10-3$ & \\
\hline Value founded & $5.0926 \times 10-3$ & $4.9975 \times 10-3$ & $5.0562 \times 10-3$ \\
\hline Recovery \% & 101.85 & 99.95 & 101.12 \\
\hline $\mathrm{RE} \%$ & 1.85 & -0.05 & 1.12 \\
\hline RSD $\%$ & 1.72 & 2.01 & - \\
\hline
\end{tabular}

Table 11. Analysis of Diclofenac sodium samples by using ISE type (DFS-MIP2 +BEHA)

\begin{tabular}{|c|c|c|c|}
\hline \multirow{2}{*}{ Pharmaceutical } & \multicolumn{3}{|c|}{ CataFlam (Novartis pharma AG, Basle, Switzerland) } \\
\hline & DM & SAM & MSAM \\
\hline Concentration $\mathrm{M}$ & & $5 \times 10-3$ & \\
\hline Value founded & $4.9493 \times 10-3$ & $5.1162 \times 10-3$ & $5.0101 \times 10-3$ \\
\hline Recovery \% & 98.94 & 102.32 & 101 \\
\hline $\mathrm{RE} \%$ & -1.01 & 2.32 & 1 \\
\hline $\mathrm{RSD} \%$ & 1.23 & 1.62 & \\
\hline Pharmaceutical & \multicolumn{3}{|c|}{ OPIFENAC-25 (Ajanta Pharma, India) } \\
\hline Concentration $\mathbf{M}$ & & $5 \times 10-3$ & \\
\hline Value founded & $4.9238 \times 10-3$ & $5.0645 \times 10-3$ & $5.0674 \times 10-3$ \\
\hline Recovery \% & 98.48 & 101.29 & 101.35 \\
\hline $\mathrm{RE} \%$ & -1.52 & 1.29 & 1.35 \\
\hline $\mathrm{RSD} \%$ & 1.28 & 2.41 & \\
\hline Pharmaceutical & \multicolumn{3}{|c|}{ Voldic-K (Pharma International CO. Amman -Jordan) } \\
\hline Concentration $\mathrm{M}$ & & $5 \times 10-3$ & \\
\hline Value founded & $4.9394 \times 10-3$ & $5.1730 \times 10-3$ & $5.0755 \times 10-3$ \\
\hline Recovery \% & 98.79 & 103.46 & 101.51 \\
\hline $\mathrm{RE} \%$ & -1.21 & 3.46 & 1.51 \\
\hline $\mathrm{RSD} \%$ & 1.097 & 1.72 & \\
\hline
\end{tabular}

Table 12. Analysis of Diclofenac sodium samples by using ISE type (DFS-MIP2 +TTP)

\begin{tabular}{|c|c|c|c|}
\hline \multirow{2}{*}{ Pharmaceutical } & \multicolumn{3}{|c|}{ CataFlam (Novartis pharma AG, Basle, Switzerland) } \\
\hline & DM & SAM & MSAM \\
\hline Concentration $\mathrm{M}$ & & $5 \times 10-3$ & \\
\hline Value founded & $5.0616 \times 10-3$ & $5.1643 \times 10-3$ & $5.0472 \times 10-3$ \\
\hline Recovery \% & 101.23 & 103.29 & 100.94 \\
\hline $\mathrm{RE} \%$ & 1.23 & 3.29 & 0.94 \\
\hline $\mathrm{RSD} \%$ & 1.86 & 2.26 & \\
\hline Pharmaceutical & \multicolumn{3}{|c|}{ OPIFENAC-25 (Ajanta Pharma, India) } \\
\hline Concentration $\mathbf{M}$ & & $5 \times 10-3$ & \\
\hline Value founded & $5.0901 \times 10-3$ & $5.0266 \times 10-3$ & $5.0761 \times 10-3$ \\
\hline Recovery \% & 101.80 & 100.532 & 101.52 \\
\hline $\mathrm{RE} \%$ & 1.80 & 0.532 & 1.52 \\
\hline $\mathrm{RSD} \%$ & 2.022 & 2.2 & - \\
\hline Pharmaceutical & \multicolumn{3}{|c|}{ Voldic-K (Pharma International CO. Amman -Jordan) } \\
\hline Concentration $\mathbf{M}$ & & $5 \times 10-3$ & \\
\hline Value founded & $4.9348 \times 10-3$ & $5.2106 \times 10-3$ & $5.0542 \times 10-3$ \\
\hline Recovery \% & 98.70 & 104.21 & 101.08 \\
\hline $\mathrm{RE} \%$ & -1.30 & 4.21 & 1.08 \\
\hline RSD \% & 2.035 & 2.54 & - \\
\hline
\end{tabular}




\section{Conclusion:}

Diclofenac sodium membranes selective electrodes can be constructed by mixing with different plasticizers. These plasticizers TEHP, TBP, BEHA and TTP were used to prepare diclofenac sodium membranes electrodes based on PVC. The results obtained for all electrodes were excellent as well as applied on standard and pharmaceutical solutions. The aim of construction electrodes for used in determination diclofenac sodium in pharmaceuticals analysis.

\section{References:}

1. Iliescu Baia TM, Miclaus VA. Raman spectroscopic study of the diclofenac sodium-betacyclo dextrin interaction, Eur. J. Pharm. Sci. 2004; (22): 487-495.

2. Yilmaz B, Ciltas U. Determination of diclofenac in pharmaceutical preparations by voltammetry and gas chromatography methods, J. Pharma. Analysis. 2015;5(3): 153-160.

3. The Merck Index, 14th Edition Whitehouse Station, NY, USA. 2006.

4. Birajdar AS, Meyyanathan S, Suresh B. ARP-HPLC method for determination of diclofenac with rabeprazole in solid dosage form, Pharm. Sci. Monit. 2011; (2):171-178.

5. Agrawal YK, Shivramchandra K. Visible spectrophotometric method for determination of diclofenac sodium, J. Pharm. Biomed. Anal. 1991; (9):97-100.

6. Khanvilkar V, Tambe A, Dalvi V, Parmar D, Kadam V. High performance thin layer chroma. method development and simultaneous estimation of tramadol hydrochloride and diclofenac sodium in bulk and formulation, Indo American J. Pharma. 2013;3(10):( 2231-6876):8440-8100.

7. Siou A, Pommier F, Godbillon J. Determination of diclofenacin plasma and urine by capillary gas chromatography-mass spectrometry with possible simultaneous determination of deuterium labeled diclofenac, J. Chromatogr. 1991; (571):(87-100).

8. Sena MM, Chaudhry F, Collins ZCH, et. al., N-way PLS applied to simultaneous spectrophotometric determination of acetylsalicylic acid, paracetamolandcaffeine, J. Pharm. Biomed. Anal. 2004; 36: 743-749.

9. Faridbod F, Zamani HA, Hosseini M, PiraliHamedani M, Ganjali MR, Norouzi P. Int. J. Electrochem. Sci. 2011;6: 3694-3703.

10. Ganjali MR, Nemati R, Faridbod F, Norouzi P, Darviche F. Int. J. Electrochem. Sci. 2008; (3):1288.

11. Ganjali MR, Karimi A., Shahtaheri S.J, Norouzi P, Int.J.Electrochem.Sci.,2013;8:1999-2008.

12. Faridbod F, Ganjali MR, Larijani B, Nasli-Esfahani E, Riahi S, Norouzi P. Conducting polymer all solid state potentiometric sensor Int. J. Electrochem. Sci., 2010; (5)13:653.

13. Mittal, SK, Kumar P, Ashok Kumar SK, Lindoy LF. Copper-selective PVC membrane sensor. Int. J. Electrochem. Sci., 2010; (5)22:1984.
14. Faridbod F, Larijani B. Ganjali MR, Norouzi, P. PVC membrane sensor for potentiometric determination of dicyclomine in pharmaceutical formulation. Int. J. Electrochem. Sci.,2012;(7):10404-10413.

15. Shishkanova TV, Sýkora D, Sessler JL, Král V. Potentiometric response and mechanism of anionic recognition of heterocalixarene-based ion selective electrodes. Anal Chim Acta.2007;587(2):247-53.

16. Bera RK, Sahoo SK, Mittal, SK, Kumar SKA. Potentiometric sensor for determination of clomiphene. Int. J. Electrochem. Sci., 2010; (5):29.

17. Ganjali MR, Norouzi P, Mirnaghi FS, Riahi SF. Faridbod, Lanthanide Recognition: Monitoring of Praseodymium (III) by a Novel Praseodymium (III) Microsensor Based on N \$'\$-(Pyridin-2-Ylmethylene) Benzohydrazide IEEE Sensors J. 2007; (7)8:11381144.

18. Zamani HA, Ganjali MR, Norouzi P, Tadjarodi A, Shahsavani E. Determination of terbium (III) ions in phosphate rock samples by a $\mathrm{Tb}^{+3}$-PVC membrane sensor based on $N, N$-dimethyl- $N, N$-bis(4methixyphenyl)phosphate. Mater. Sci. Eng. C, 2008; (28):1489-94.

19. Mersal GAM, Arida HA. New carbon paste modified micro electrode based on haematoxylin for determination of aluminum in underground water Int. J. Electrochem. Sci., 2011; 6:1116-1126.

20. Al-Bayati YK, Al-jabari FI. Constraction of new selective electrodes for determination ibuprofen and their application in pharmaceutical samples. IJRPC. 2015; 5(3):380-389.

21. Al-Bayati YK, Al-Saidi KH, Hussain MA. Liquid selective electrodes for warfarin sodium based on poly(vinyl chloride) matrix membrane ,Asian journal of chemistry. 2016; 18(9):1962-1966.

22. Al-Bayati YK, Karabat RR. potentiometric study of phenytoin-PVC membrane electrodes for determination of phenytoin in pharmaceutical preparations, Journal of Al-Nahrain University. 2015; 18(1):79-87.

23. Al-Bayati YK, Al Khafaji IH. Synthesis of New Selective Electrodes for the Determination of Metronidazole Benzoate (MNZB) Based on a Molecularly Imprinted Polymer Combined With Poly Vinyl Chloride. IJCRGG. 2017; 10(3):552-561.

24. Moody GJ, Thomas JDR. Organic sensor materials in entangled and polymer-bound matrices for ion selective electrodes. Chemical Sensors. 1988; 75-116.

25. Mahajan RK, Sood P. Novel Copper (II)- Selective Electrode Based on 2,2': 5',2' '-Terthiophene in PVC Matrix. Lnt.J.Electrochemcal Sci. 2007; 2:832-847.

26. Sohail RM. De Marco, Curtin University. Curtin research publication. Electrodes ion-selective electrodes, Reference Module in Chemistry, Molecular Sciences and Chemical Engineering. 2013

27. Umezawa Y, Katoka U, Hitoshi S. Selectivity coefficients for ion-selective Electrodes: recommended methods for reporting KA, B values. Pure \& Appl. Chem. 1995; 67(3):507-518. 
تخليق وتوصيف الطبعة البوليمرية الجزيئية للايكلوفيناك صوديوم باستخذام 2-فاينيل بريدين و 2هايدروكسي اثيل ميثا اكريليت كمونمرات معقدة

\author{
احمد جليل الصافي2
}

\author{
يحيى كمال البياتي
}

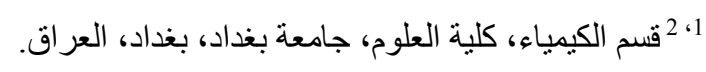

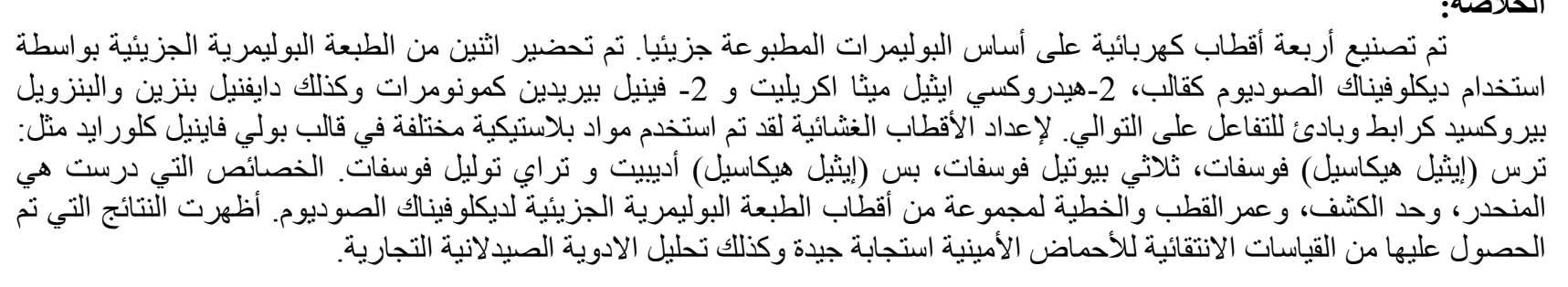

الكلمات المفتاحية: اقطاب الطبعة البوليمرية، دايكلوفيناك صوديوم، الطريقة المجهادية (بوتينشيومنرك)، مونومرات 2-هيدروكسي ايثيل ميثا اكريليت، 2 - فينيل بيريدين. 